\title{
WHERE IS CRITICAL THEORY? EUROCENTRISM AND MARGINALIZATION IN EUROPEAN AND AMERICAN CRITICAL THEORY
}

\author{
ONDE ESTÁ A TEORIA CRÍTICA? EUROCENTRISMO \\ E MARGINALIZAÇÃO NA TEORIA \\ CRÍTICA EUROPÉIA E AMERICANA
}

DÓNDE ESTÁ LA TEORÍA CRÍTICA? EUROCENTRISMO
Y MARGINACIÓN EN LA TEORÍA CRÍTICA
EUROPEA Y AMERICANA

ARNOLD FARR ${ }^{\mathrm{I}}$

\begin{abstract}
In this paper, I will examine the marginalization of certain forms of critical theory in US. I will argue that the real Great Refusals have been refused by much of what calls itself critical theory. What gets accepted as critical theory in the academy is often connected to the social position of those doing the theory. That is, quite often critical theory is constructed by those who enjoy a certain degree of social comfort and have created a gap between themselves and the "wretched of the earth" who suffer daily. Critical Theory becomes Ivory Tower theorizing. Finally, I will argue that Herbert Marcuse was a critical theorist who tried to stay connected to those who suffer. I will make some proposals based on Herbert Marcuse's critical theory of education, the black feminist framework of intersectionality, and what I call democratic attunement.
\end{abstract}

Keywords: Critical Theory, Eurocentrism, Marginalization, Europe, America

REsumo Neste artigo, examinarei a marginalização de certas formas de teoria crítica nos EUA. Argumento que as grandes recusas reais foram abandonadas por muito do que se chama de teoria crítica. O que é aceito como teoria crítica na academia geralmente está ligado à posição social daqueles que fazem a teoria. Ou seja, muitas vezes a teoria crítica é construída por aqueles que gostam certo grau de conforto social e criou uma lacuna entre

Universidade de Kentucky (UK). Estados Unidos 
eles e os "Desgraçados da terra" que sofrem diariamente. A teoria crítica torna-se a teorização da Torre de Marfim. Finalmente, argumentarei que Herbert Marcuse era um teórico crítico que tentava ficar conectado àqueles que sofrem. Vou fazer algumas propostas baseadas na teoria crítica de Herbert Marcuse sobre Educação, no quadro feminista negro da interseccionalidade e no que eu chamo de sintonia democrática.

Palavras-chave: Teoria Crítica, Eurocentrismo, Marginalização, Europa, América

Resumen En este artículo, examino el margen de ciertas formas de teoría crítica en los Estados Unidos. Argumento que como grandes rechazos reales fueron abandonados por mucho de lo que se llama teoría crítica. Lo que se acepta como teoría crítica en la academia generalmente está ligado a la posición social de aquellos que hacen una teoría. Es decir, muchas veces, una serie de críticas y construcciones por aquellos que les gusta cierto grado de confort social y ha creado una laguna entre ellos y los "Desgraciados de la tierra" que sufren diariamente. La teoría se convierte en una teorización de la Torre de Marfil. Finalmente, argumentaré que Herbert Marcuse era un teórico crítico que intentaba estar conectado a aquellos que sufren. Voy a hacer algunas propuestas basadas en la teoría crítica de Herbert Marcuse sobre Educación, en el cuadro feminista negro de la interseccionalidad y en lo que yo llamo la sintonía democrática.

Palabras clave: Teoría Crítica, Eurocentrismo, Marginación, Europa, América

\section{INTRODUCTION}

Too often critical theory is simply associated with a specific European philosophy and form of discourse. Academic philosophy is very narrow in what it accepts as legitimate critical theory. The result is that forms of critical theory in the Americas that are more faithful to the goals of Frankfurt School critical theory with regards to the unity of theory and practice gets ignored, excluded, or marginalized. It is as if theory that directs itself toward practice has no place in the academy.

In this paper, I will examine the marginalization of certain forms of critical theory in US. I will argue that the real Great Refusals have been refused by much of what calls itself critical theory. What gets accepted as critical theory in the academy is often connected to the social position of those doing the theory. That is, quite often critical theory is constructed by those who enjoy a certain degree of social comfort and have created a gap between themselves and the "wretched of the earth" who suffer daily. Critical Theory becomes Ivory Tower theorizing. Finally, I will argue that Herbert Marcuse was a critical theorist who tried to stay connected to those who suffer. I will make some proposals based on Herbert Marcuse's critical theory of education, the black feminist framework of intersectionality, and what I call democratic attunement.

I am aware that the first few words of my title may sound strange. Sometimes it is that which is strange that gets our attention. Further, a strange title may merely reflect the 
strangeness of the social reality that one is trying to come to terms with. Such strange language may be an attempt to disrupt our traditional or conventional way of thinking about things. What can it mean to ask "where is critical theory"?, when it is obvious where it is. It is in several texts written by a handful of white male (mostly Jewish) Freudo/Marxists theorists who were exiled in the 1930s to the US from Germany. It is their texts (as well as those of Marx) and the texts of latter generations of scholars who think of themselves as in some way carrying out the project of this group of theorists from Frankfurt Germany. This is the conventional understanding of the location of critical theory and it is the very view that undermines the project of critical theory. Critical theory seems to be located in the minds and texts of a handful of white males in Europe and the US. But are there equally powerful and relevant critical theories beyond and alongside this version of critical theory? ${ }^{1}$ To not recognize the multiple forms of critical theory is to develop a critical theory that is perhaps still useful but also greatly impoverished. First, we need to be clear about what the project of critical theory is and then critique its Eurocentric nature while using the tools provided by critical theory to work toward a critical and non-Eurocentric theory of emancipatory education.

\section{Critical Theory According to its Founders}

In his programmatic essay "Traditional Theory and Critical Theory", Max Horkheimer writes:

But the critical theory of society is, in its totality, the unfolding of a single exis-
tential judgement. To put it in broad terms, the theory says that the basic form
of the historically given commodity economy on which modern history rests
contains in itself the internal and external tensions of the modern era; it genera-
tes these tensions over and over again in an increasingly heightened form; and
after a period of progress, development of human powers, and emancipation
for the individual, after an enormous extension of human control over nature, it
finally hinders further development and drives humanity into a new barbarism.

In this description of critical theory, Horkheimer giveth and taketh away at the same time. He giveth insofar as he is right to point out that the modern form of the commodity economy generates tensions which undermine human progress in its control over nature by producing a new barbarism. However, according to this description, critical theory operates

1 Stefan Gandler has done a wonderful job exploring the importance of non-European forms of critical theory in Mexico. There what he calls critical Marxism develops in a place very different from Europe. As a result of the unique form of domination that theorists had to deal with in Mexico their theories provided insight that are neglected by Eurocentric forms of critical theory. See, Stefan Gandler, Critical Marxism in Mexico: Adolfo Sánchez Vázquez and Bolívar Echeverría, (Chicago, Il: Haymarket Books, 2015).

2 Max Horkheimer, "Traditional and Critical Theory" in Critical Theory: Selected Essays Max Horkheimer translated by Matthew J. O'Connell and others, (New York: The Seabury Press, 1972). p. 227. 
within an economic framework. Although the critique of political economy is essential for the development of an emancipatory theory, such a theory must not be limited to such. I am aware that the Frankfurt School included in their critique of capitalism, political, cultural, and psychological critiques. However, even these critiques were guided by the absence of a revolution against capitalism. Intertwined with the struggle against economic injustice are many other struggles which cannot be reduced to the struggle against economic injustice. I am thinking here of struggles against racism, sexism, homophobia, the destruction of the environment, European and US imperialism etc.

It is interesting that the quote by Horkheimer reminds one of a few passages from Dialectic of Enlightenment, by Horkheimer and Adorno. They are very clear about how progress in the human control over nature, or better put, the human domination of nature has led to the domination of some human beings by other human beings. Anti-black racism is never mentioned. This is one of the most obvious cases of the domination of one group of human beings by another. Indeed, there is an incredibly large "philosophical" and "scientific" literature that justifies slavery and the domination of people of African descent by claiming that people from Africa were closer to nature than humanity and therefore not fully human. I suspect that one could find similar literature and sentiments here in Brazil. Nevertheless, my goal at this point is not to address the Eurocentric nature of Frankfurt School yet. Here, we are merely trying to understand what the project of critical theory is according to its founders so that we may later critique this project in light of its limitations. To that end, I turn to Marcuse's understanding of the project of critical theory.

In his own programmatic essay "Philosophy and Critical Theory", Marcuse develops a theme that is also found in his 1941 book on Hegel Reason and Revolution. That theme is that the philosophical construction of reason is to be replaced by the creation of a rational society. Philosophy, and especially German idealism, is concerned with human freedom and a better world. However, he wonders, "what if the forces that were to bring about that transformation are suppressed and appear to be defeated?"3 He responds as follows:

Little as the theory's truth is thereby contradicted, it nevertheless appears then in a new light which illuminates new aspects and elements of its object. The new situation gives a new import to many demands and indices of the theory, whose changed function accords it in a more intensive sense the character of "critical theory." Its critique is also directed at the avoidance of its full economic and political demands by many who invoke it. This situation compels theory anew to a sharper emphasis on its concern with the potentialities of man and with the individual's freedom, happiness, and rights contained in all of its analyses. For the theory, these are exclusively potentialities of the concrete social situation. They become relevant only as economic and political questions and as such bear on human relations in the productive process, the distribution of the product of social labor, and men's active participation in the economic and political administration of the whole. ${ }^{4}$

3 Herbert Marcuse, "Philosophy and Critical Theory" in Negations: Essays in Critical Theory translations by Jeremy J. Shapiro, (Boston: Beacon Press, 1968). p. 142.

4 Ibid., p. 142-143. 
Like Marx, Marcuse believed that the realization of reason in the world would make the need for philosophy disappear. Marx believed that philosophy is fulfilled when social conditions make it no longer necessary. However, Marx and Marcuse differ from their German idealist predecessors by recognizing that social reality tends to contradict the truth of philosophy. In this situation then philosophy must become critical theory which concerns itself with economic and political questions regarding the potentialities of human beings as well as freedom, rights, and happiness. This critique must address any social, political, economic, cultural, and psychological mechanisms that hinder optimum development for all human persons. Along these lines, a passage from the introduction to One-Dimensional Man by Marcuse is useful.

From the beginning, any critical theory of society is thus confronted with the problem of historical objectivity, a problem that arises at the two points where the analysis implies value judgments. 1 . The judgment that human life is worth living, or rather, can be and ought to be made worth living. This judgment underlies all intellectual effort; it is the a priori of social theory, and its rejection (which is perfectly logical) rejects theory itself. 2 . The judgment that, in a given society, specific possibilities exist for the amelioration of human life and specific ways and means of realizing these possibilities. Critical analysis has to demonstrate the objective validity of these judgments, and the demonstration has to proceed on empirical grounds. The established society has available an ascertainable quantity and quality of intellectual and material resources. How can these resources be used for optimal development and satisfaction of individual needs and faculties with minimum toil and misery? ${ }^{5}$

The problem of historical objectivity already moves us beyond abstract philosophy insofar as the historical is given some priority. Although the question of whether human life is worth living or should be made worth living still involves some speculative work it is nevertheless objective and historical. This judgment is objective because it refers to all human life and not just a particular human life. It is historical because any response to it requires historical considerations. The historical element is best explained by the second judgment. Even though Marcuse has been accused of being a Utopian thinker, that accusation is incorrect. Marcuse's form of critical theory is dialectical insofar as it discloses two contradictory forces at work at the same time in the same society; the possibility for liberation; and the possibility for further oppression. The present order of things contains within itself the possibility for being otherwise. Marcuse's also engages in what later critical theorists such as Axel Honneth and Selya Benhabib will call immanent critique. An immanent critique is a critique of a society not on the basis of external criteria, but rather, on the basis of possibilities contained in the very society in question. Hence, any theory about the amelioration of humanity must be based on the actual presence of ameliorative possibilities in that society. Such a view is not a blind utopianism. Marcuse makes this very point in the following way.

5 Herbert Marcuse, One-Dimensional Man (Boston: Beacon Press, 1964) p. x-xi. 
But in my opinion there is one valid criterion for possible realization, namely, when the material and intellectual forces for the transformation are technically at hand although their rational application is prevented by the existing organization of the forces of production. And in this sense, I believe, we can today actually speak of the end of utopia. ${ }^{6}$

Marcuse claims that the material and intellectual resources that are necessary for the realization of a free society are already present in our society. It is a matter of how these resources are put to use. This is similar to his claim in Eros and Civilization, that scarcity is no longer a problem in western societies, the problem is the distribution of scarcity. It is the specific organization of a society and its material as well as intellectual resources that make liberation a real possibility or an, impossibility. The task of the critical theorist is to disclose the possibilities before us for liberation as well as the restrictions on those possibilities. This can all be summed up by what Douglas Kellner calls the three Cs of critical theory. Kellner writes: "From a methodological point of view, critical theory is at once to comprehend the given society, criticize its contradictions and failures, and to construct alternatives."

Now, it may seem that so far I've not worked within the boundaries of the title of my own paper. However, things are not always what they seem. Since we have to come together to critique some of the failings of critical theory and to question what we find to be a bit of Eurocentrism in critical theory, it is necessary to clearly define the project of critical theory as it is presented by its founders. What we find is the right attitude with regards to critique and emancipation but a limitation to the effectiveness of critical theory that its definition does not contain. This tedious process opens the door for the critique of critical theory in the rest of this paper.

The begin with, all of the limitations of critical theory can be traced back to the first $\mathrm{C}$ of critical theory, comprehension. The comprehension of our oppressive society by the early critical theorists was unfortunately limited to the framework of political economy. Although Marcuse often tried to extend his theory beyond this framework, he did not go far enough. If, as we have seen from Horkheimer and Marcuse, the goal of critical theory is the amelioration of the human species then we must be clear and have a comprehensive knowledge of the sources of human misery, domination, alienation, exploitation, and dehumanization. What are the social, political, economic, cultural, and psychological mechanisms that block the attempt to ameliorate humanity? Any look at human struggles for emancipation around the world will reveal that the source of suffering is not merely economic. However, even when the source of suffering and dehumanization is economic, that struggle may disclose itself differently than those in Europe and America. Political and social struggles and the theorizing that they give birth to may very well improve the

6 Herbert Marcuse, "Marxism, Revolution, and the Contemporary Moment" in Herbert Marcuse: Marxism, Revolution, and Utopia, edited by Douglas Kellner, (London and New York: Routledge, 2014). p. 250-251.

7 Douglas Kellner, Herbert Marcuse and the Crisis of Marxism (Hampshire and London: Macmillan, 1984). p. 122-123. 
Eurocentric understanding of struggles against injustice and dehumanization. Here I would like to briefly examine one of the cases where the Eurocentrism of the Frankfurt School failed the test of comprehension with regards to struggles for liberation. That is, where is the critique of racism and its structures in critical theory?

\section{DOES BLACK LIVES MATTER FOR CRITICAL THEORY?}

One of the topics that some of us have talked about over the past few days is critical theory and racism. I want to change the language a bit and use the term racialized consciousness instead of racism. Although racism is alive and well it is not easy to detect all of the ways in which racism may manifest itself. It is important for us to distinguish between a form of racism that is conscious and intentional, a form of racism that is a conscious commitment to the system of white supremacy (and I might add European supremacy, Eurocentrism), and a form of racism that is not conscious or intentional. In my own work I have chosen to use the term racialized consciousness to describe an unintentional and unconscious form of racism. I want to briefly discuss two examples of this. One of the examples is that of a contemporary movement in the US. The other is an example from the history of Frankfurt School Critical Theory.

Many of you are probably familiar with the Black Lives Matter movement in the US. This movement is a response to the random killings of unarmed black people by white policemen and even regular citizens like George Zimmerman. Although this movement is an attempt to end racism it has been called racist by not only regular white citizens but also by some politicians. It has also been interpreted as an anti-police movement. However, both of these accusations are completely false. The movement is nothing more than a demand that policemen and all others be held accountable for their actions when a life is unjustifiably taken. However, some white people in the US have attempted to counter this movement with an All Lives Matter movement. The "all" is a universal signifier that turns our attention to all persons and not a specific group. However, the contradiction here is that in the real concrete world where we live "all" does not mean all. The daily experience of black people in the US, especially those in the inner city, is that their black lives do not matter. In the US, blackness tends to signify criminality in the minds of many white people. The "all" in All Lives Matter is an abstraction that puts under erasure the reality of the unjustifiable criminalization of black people and black suffering. Some of the followers of the All Lives Matter movement are not conscious, intentional racists. However, they are products of a system of white supremacy and white privilege. Their privileged social position makes them insensitive to black suffering. These people live in a solidly white world that shields them from the plight of black people.

The "All Lives Matter" movement is typical of a systemic and systematic avoidance of dealing with oppression by those who benefit from the oppression of others, or are too comfortable in their own privileged space to notice the day-to-day suffering of the oppressed. The tendency to prematurely universalize produces the type of contradictions 
that I am concerned with here. Adorno was aware of this problem and tried to combat it but somehow was still victim to it as he seemed oblivious to certain concrete struggles for liberation. I will address this is a moment. The tendency to universalize to quickly puts under erasure real day-to-day human experience. The black feminist sociologist Patricia Hill Collins captures this very well in her reflection on the black slave liberator Sojourner Truth. She cites Truth as follows:

\begin{abstract}
That man over there says women need to be helped into carriages, and lifted over ditches, and to have the best place everywhere. Nobody ever helps me into carriages, or over mud-puddles, or give me any best place! And ain't I a woman? Look at me! Look at my arm! I have ploughted, and planted, and gathered into barns, and no man could head me! And ain't I a woman? ${ }^{8}$
\end{abstract}

In this passage, we find a clear example of the way in which universal claims about humanity or even a part of humanity radically fails to include all human beings or individual members of a group that has been attributed some universal quality or qualities. Truth, however, immediately recognizes the false nature of the claim about women. She is obviously a woman but the claims made about women do not apply to her for she is a particular kind of woman, a black woman. Her blackness places her in a situation that is not occupied by white women. Therefore, any attempt to understand her or relieve her of her suffering demands paying attention to her particularity, paying attention to how her life and opportunities, and her daily engagement with the world is conditioned by her blackness or the way in which white people interpret and respond to blackness. The constant appeal to the universal by those who are not members of oppressed groups becomes a way of not seeing and therefore not having to engage the system and practices by which particular groups of people are victimized.

The "All Lives Matter" movement as a response to the "Black Lives Matter" movement is based on a refusal to see and engage with the daily victimization of black people by whites in authority. Even well intentioned white people who are liberal in their political orientation and in their minds oppose racism can be victims of what I am calling racialized consciousness. When Obama was elected President in 2008, many of my white liberal friends began to talk about a post racist America. I knew then and we all know now that such a thing does not exist. White liberals, who are not intentional racist, are so embarrassed by racism that they are too eager to celebrate the end of racism. They always do this without actually talking about the matter with black people, especially black people from the inner city. Their claim to be color-blind protects them from seeing the hard reality of black life in America. The day-to-day suffering of many black people is not noticed by the majority of white people who do not live in black communities. The question now is can the critical theorist be guilty of such blindness and racialized consciousness.

8 Patricia Hill Collins, Black Feminist Thought (New York and London, 1991) p. 14. 
The case of Angela Y. Davis will disclose the whiteness of critical theory and perhaps its sexism at two levels. First, there is the fact that even though she studied in Frankfurt with Adorno and Horkheimer, and came back to write her dissertation with Marcuse, and spent her entire life working as an activist and educator, she is not mentioned in any histories of critical theory. Davis has achieved global recognition for her work but has been sidelined by historians of critical theory. The whiteness of critical theory also reveals itself at a second level. While studying philosophy in Frankfurt with Adorno and Horkheimer, Davis was becoming more and more concerned about the black struggle for liberation taking place in the US in the 1960s. Davis recalls her struggle, as follows:

The more the struggles at home accelerated, the more frustrated I felt at being forced to experience it vicariously. I was advancing my studies, deepening my understanding of philosophy, but I felt more and more isolated. I was so far away from the terrain of the fight that I could not even analyze the episodes of the struggle. I did not even have the knowledge or understanding to judge which currents of the movement were progressive and genuine and which were not. It was a difficult balance I was trying to maintain, and it was increasingly hard to feel a part of the collective coming to consciousness of my people. ${ }^{9}$

The black struggle for liberation in America represented a real moment of transformative social and political praxis. It was a moment that demanded all resources available, material and intellectual as Marcuse suggest. While in Frankfurt, Davis felt more and more isolated from the transformative praxis that critical theory claims to support. Her desire to be a part of this transformative movement in the US was met with disdain by Adorno. She writes:

I have often publicly expressed my gratitude to Herbert Marcuse for teaching me that I did not have to choose between a career as an academic and a political vocation that entailed making interventions around concrete social issues. In Frankfurt, when I was studying with Adorno, he discouraged me from seeking to discover ways of linking my seemingly discrepant interests in philosophy and social activism. ${ }^{10}$

Marcuse seemed to have a better understanding of Davis's concerns and he was more open to her political activism. This puts Marcuse in a better place than Adorno with regards to the need for theory as well as transformative political activity. However, Marcuse's position was still the result of his ongoing struggle with his own Eurocentrism. Again, it is amazing that when members of the Frankfurt School were exiled to the US, segregation and various forms of and manifestations of white supremacy, as well as sexism were very visible. However, they by-and-large remained silent on these issues. The lack of writing on racism and the black struggle for liberation by members of the Frankfurt School depicts a

9 Angel Davis, Angela Davis: An Autobiography (New York: International Publishers, 2006) p.144-145.

10 Angela Davis, "Preface: Marcuse's Legacy" in Herbert Marcuse, Herbert Marcuse: The New Left and the 1960s, Edited by Douglas Kellner (London and New York: Routledge, 2005) p. xi 
certain blindness that one can only attribute to their inability to see the world through non-European lenses. Marcuse, however, was willing to learn from his students. In a letter to Angela Davis, he writes:

The world in which you grew up, your world (which is not mine) was one of cruelty, misery, and persecution. To recognize these facts did not require much intelligence and sophistication, but to realize that they could be changed and must be changed required thinking, critical thinking: knowledge of how these conditions came about, which forces perpetuated them, and of the possibilities of freedom and justice. This, I believe, you learned in your years of study. In addition, you learned something else, namely, that almost all the celebrated figures of Western civilization - the very civilization which enslaved your people - were in the last analysis concerned with one thing: human freedom. Like any good student, you took seriously what they said, and you thought seriously about it, and why all this had remained mere talk for the vast majority of men and women. Therefore, you felt that the philosophical idea, unless it was a lie, must be translated into reality: that it contained a moral imperative to leave the classroom, the campus, and to go and help others, your own people to whom you still belong - in spite of (or perhaps because of) your success within the white Establishment. But you fought for us too, who need freedom and who want freedom for all who are unfree. In this sense, your cause is our cause. ${ }^{11}$

Marcuse and Davis both were great students of Marx's Eleventh Thesis on Feurerbach, "The philosophers have only interpreted the world, in various ways; the point is to change it." 12 Marcuse was aware that while philosophers were concerned about human freedom, they wrote about freedom merely as an idea and therefore, failed to properly understand the role of concrete political engagement in transforming the world so that freedom would be more than a mere idea, but would take on material existence in the lives of the hitherto unfree. However, this transformative engagement demands that we pay attention to the concrete forms of social, political, economic, gendered, and racialized forms of domination. Davis gave legs to critical theory so that it might be able to walk among those who were engaged in transformative praxis.

In the passage, Marcuse recognizes the limitation of his own vision as he points out that he and Davis are from different worlds. Having not shared Davis's experience of American anti-black racism, Marcuse knew that he could not fully understand the sense of urgency that drove Davis. However, Marcuse also recognized that the work for black liberation had the potential to enhance the possible success of all freedom struggles. He recognized the need for solidarity between those who are dominated by the power elite.

11 Herbert Marcuse, "Dear Angela" in Herbert Marcuse: The New Left and the 1960s Edited by Douglas Kellner (London and New York: Routledge, 2005) p. 50

12 Karl Marx, Karl Marx: Selected Writings, Edited by David McLellan (Oxford and New York: Oxford University Press, 2000) p. 173 
Of the first generation critical theorists, Marcuse provided us with the best possibility for getting beyond the Eurocentrism of critical theory. His own efforts to understand and be in solidarity with students as if Angel Davis opened him up to a wider range of forms of domination as well as the possibilities for liberation. In the next section of this paper, I will explore some ideas developed by Marcuse and further develop them with the help of black feminist thought.

\section{CONCLUSION: DEMOCRATIC ATTUNEMENT, AND EDUCATING FOR A NEW SENSIBILITY}

One of the great merits of Marcuse's form of critical theory is that it provides us with the necessary tools for getting beyond the Eurocentrism of traditional critical theory while remaining true to the original purpose of critical theory. One such tool is the concept of the "new sensibility." It may not be immediately clear how the concept of the new sensibility can help overcome the Eurocentric nature of traditional critical theory. Although Marcuse does not use the term that often and he never clearly defines it, one can deduce from his writings some idea of what a new sensibility is and how it is to be cultivated. The development of a new sensibility would have the effect of disrupting the social and political narrative whereby a Eurocentric identity is formed.

The most developed discussion of the new sensibility occurs in Chapter Two of $A n$ Essay on Liberation. There Marcuse claims that it is the ascent of the life instincts over aggressiveness. ${ }^{13}$ He adds:

The new sensibility has become, by this very token, praxis: it emerges in the
struggle against violence and exploitation where this struggle is waged for es-
sentially new ways and forms of life: negation of the entire Establishment, its
morality, culture; affirmation of the right to build a society in which the aboli-
tion of poverty and toil terminates in a universe where the sensuous, the playful,
the calm, and the beautiful become forms of existence and thereby the Form of
society itself. ${ }^{14}$

We see that the new sensibility is a transformative form of praxis whereby the entire social order of things is transformed. It is a decisive rejection of what Marcuse calls in Eros and Civilization the performance principle. If understood within the context of Marcuse's entire critical theory we see that the new sensibility would make it possible to move beyond the Frankfurt School obsession with the critique of political economy. Critical theory would expand its analysis to forms of domination that go well beyond the problem of production. It is here that Marcuse goes beyond his Frankfurt School colleagues and Marx. In a lecture which has been published as "Marxism and the New Humanity: An Unfinished Revolution," Marcuse argues that socialism would require a new type of man or a new humanity.

3 Herbert Marcuse, An Essay on Liberation, (Boston: Beacon Press, 1969) p. 23

14 Ibid, p. 25 
The development of socialist institutions and relationships requires, rather, a new type of man, a different type of human being, with new needs, capable of finding a qualitative different way of life, and of constructing a qualitatively different environment. ${ }^{15}$

The point here is that the transformation of society demands the total transformation of the human being. It is not clear how this would happen, but there are some clues in Marcuse's theory of education. In a lecture given in 1968 at Brooklyn College, the theme of the new sensibility occurs again as Marcuse suggests that creating the subjective conditions for a free society requires a new type of human being as educator. Education is viewed as Bildung or the cultivation of the self rather than the mere acquisition of a skill set. Such an education must go beyond the classroom insofar as the whole person and every part of his or life must be transformed. ${ }^{16}$

In another lecture given in 1975, at Berkeley, Marcuse gives a clearer picture of what has to happen inside and outside of the classroom. He calls for institutions that will reschool the population. Marcuse calls for a history, not of the victors of history, but of the victims. He urges the students to insist on the "missing courses." That is, reschooling for a new sensibility, a free society, and I will add a non-Eurocentric attitude demands that we increase our focus on the oppressed and dehumanized of history our in Walter Benjamin's words the ruins of history. ${ }^{17}$

Marcuse's awareness of the multiple forms of oppression in a given society and the way in which these forms of oppression support each other in some ways adumbrates the development of the framework of intersectionality developed by black feminists in the US. Black feminists, however, did not merely observe the various forms of oppression in their society. They lived these multiple forms of oppression and experienced them through their own bodies. Their very identities were constituted by the intersection of multiple oppressions. Patricia Hill Collins writes:

However, the emerging paradigm of intersectionality problematizes this entire process of group construction. As a heuristic device, intersectionality references the ability of social phenomena such as race, class, and gender to mutually construct one another. One can use the framework of intersectionality to think through social institutions, organizational structures, patterns of social interactions, and other social practices on all levels of social organization. Groups are constructed within these social practices, with each group encountering a distinctive constellation of experiences based on its placement in hierarchical

15 Herbert Marcuse, "Marxism and the New Humanity: An Unfinished Revolution" in Herbert Marcuse: Marxism, Revolution and Utopia, Edited by Douglas Kellner and Clayton Pierce (London and New York: Routledge, 2014) p. 343

16 Herbert Marcuse, "Lecture on Education, Brooklyn College, 1968" in Marcuse's Challenge to Education Edited by Douglas Kellner, Tyson Lewis, Clayton Pierce, and K. Daniel Cho (Lanham, Boulder, New York, Toronto, and Plymouth, UK: Rowman and Littlefield Publishers, INC, 2009) p. 35

17 Herbert Marcuse, "Lecture on Higher Education and Politics, Berkeley, 1975" in Marcuse's Challenge to Education p. 43 
power relations. African-American women, for example, can be seen both as a group that occupies a distinctive social location within power relations of intersectionality and as one wherein intersectional processes characterize Black women's collective self-definitions and actions. ${ }^{18}$

The framework of intersectionality opens the door for a non-Eurocentric critical theory insofar as it points to a physical site where the three Cs of critical theory that I mentioned earlier are set to work. This site is the black, female body. The black, female body is the location or intersecting point for economic exploitation, racism, sexism and homophobia for lesbians. It is the site of the victims of history. Of course, we can go well beyond the black female body in our attempt to relocate critical theory. I just begin here because it is black feminists who have given us the framework of intersectionality.

The future success of critical theory demands a deeper connection to the victims of history, the marginalized and forgotten. This deeper connection would reveal to the critical theorist the various forms of oppression from which the victims of history suffer. The critical theorist is forced to think beyond his or her Eurocentric ways of seeing and beyond the economic framework. Indeed, the critical theorist would be more sensitive to the complex ways in which the economic framework is supported by other mechanisms of domination such as racism and sexism. The critical theorist must achieve what I call democratic attunement. [Note on willett].

The notion of democratic is require at the level of comprehension, the first of the three Cs of critical theory. Proper comprehension of society requires being attuned to the many victims and forms of victimization in society. Attunement is similar to empathy. However, empathy does mean that one completely understand the victim as if one can stand in the victims shoes. It does means putting one's self in a position to hear and be moved by the victim. This attunement to the victim necessitates a change in one's self. An example from my personal experience might serve as one of the best explanations of democratic attunement.

Although I learned to challenge the homophobia that was instilled in me during my youth, I discovered some twenty years ago, even after I had openly supported gay rights, that I was not democratically attuned to members of the gay community. I grew up with a gay brother and uncle. Although I never criticized them as other members of the family did, I realized that I was complicit in their oppression. I my youth, my two straight brothers and I would always take our new girlfriends home to meet our mom and dad. This was always a special occasion. It suddenly occurred to me twenty years ago that my gay brother could never bring his lover home to meet the family. This led me to understand the ways in which I silently tolerated the oppression and suffering of my brother and uncle. On my next trip home to South Caroline I apologized to both of them and asked their forgiveness for my negligence. This conversation had a huge impact on both of them. I even suggested that my female partner and I would go on double dates with them and whomever they were seeing.

18 Patricia Hill Collins, Fighting Words: Black Women \& the Search for Justice (Minneapolis and London: University of Minnesota Press, 1998) p. 205 
My sudden awareness of my silent participation in the oppression of my brother and uncle was a form of attunement wherein I was able to imagine how they experience the world. Of course, my knowledge was greatly incomplete which meant that I needed to learn more by hearing them. I had to, at least theoretically, visit their space, locate myself with them. This meant that I had to leave my place of comfort and deal with my ignorance and uneasiness. This attunement was democratic insofar as it creates a critical and emancipatory discourse between those involved. It also initiates the process of dismantling the systems and attitudes by which the victims are victimized and it creates solidarity.

I mention this experience because traditional critical theory would do well to consider the framework of intersectionality and democratic attunement if it is to properly comprehend society so that its critique and construction of a solution would adequately resolve the problem of domination and oppression in our world. If critical is to be non-Eurocentric these tools must be taken up.

\section{DADOS DO AUTOR}

\section{Arnold Farr}

Doutor em filosofia pela Universidade de Kentucky. Professor da Universidade de Kentucky. Estados Unidos. arnold.farr@uky.edu

Submetido em: 17-4-2017

Aceito em: 27-6-2017 